\title{
091 \\ Identification of economic vulnerability of tsunami affected fishing community in Sri Lanka for rehabilitation and reconstruction: A Case study of tsunami affected fishing community in Kalutara district
}

\author{
M M Fonseka ${ }^{1}$, R L T N Rajapakshe ${ }^{2}$ and D A C Silva ${ }^{3}$ \\ 'Board of Business Administration, Postgraduate Insititute of Agriculture (PGIA), \\ University of Peradeniya, Sri Lanka, \\ 2Department of Agribusiness Management, Wayamba University of Sri Lanka, Sri Lanka. \\ ${ }^{3}$ Department of Economics, University of Colombo, Sri Lanka
}

The Indian Ocean Tsunami that hit the country on 26 December 2004 has had severe impact on Fisheries Industry. It affected the Fisheries infrastructures and community in 12 out of 14 coastal districts. This study examined the impacts on the vulnerability of fishing community of Kalutara district and the impact of the tsunami relief and rehabilitation activities on the level of vulnerability of this community.

A Survey was conducted at Three Fisheries Inspector (FI) Divisions in Kalutara District and composite vulnerability indices were computed by using Normalization method. The variables of income per month, expenditure per month, number of dependents, number of fishing days per month, Land size, value of productive assets, savings per month, loans taken and age of household head were taken into account for the computation of Composite Vulnerability Index. Results showed that composite vulnerability index is 0.41 and fishing community of Kalutara District is in average level of vulnerability.

The short-term rehabilitation and reconstruction strategies and programmes implemented to assist tsunami affected community to rebuilt their livelihood assets, re-establish their fishing activities and start fish marketing, processing and distribution showed some success in Kalutara District. However, institutional support facilities and services are not fully completed. To smooth implementation, effective coordination will be required for channelling of official and private funds and improved co-ordination and communication among the various agencies be critical for rehabilitate and reconstruct on fishing community.

This composite vulnerability computation, which can be applied to evaluate effectiveness and success of strategies and programmes, implemented at different time and locations.

\section{2}

\section{Tsunami and its impact on fisheries industry in Hambantota district of Sri Lanka}

\author{
J W D Chaminda, P G S A Jayarathne and S Amaratunge \\ Faculty of Management Studies and Commerce, \\ University of Sri Jayewardenepura, Sri Lanka
}

December 26, 2004 the earth quake occurred close by the Sumathra Islands created a tsumani situation at north, east and south region of Sri Lanka and caused heavy damages killing over 30,000 people, destroying over 100,000 homes and weakening the livelihood of the victims. Also, the natural ecosystems, and coastal infrastructure were destroyed to a great extent. Twenty percent of the coastal population affected in Hambantota district and more than seventy percent were affected in north and east regions. Fisheries industry experiences a large amount of losses among the affected economic sectors and industries. Not only the livelihood of the people who are directly involved in fishing but also the livelihood of the people in related industries, were impacted by the disaster. In general, death, displacements, and damages to the fishing boats and fishing harbors are the results of the Tsunami which pave the way to an economic and social crisis in the country. As it discloses the significant direct impact to fisheries industries and to the nation at large, the purpose of this study is to asses the damage and inquire the needs for those who engaged in fisheries and related industries in Hambantota district. Godawaya village in Hambantota district is selected for the study as it is one of the villages involving in different sub sectors of the fisheries industry and it has been seriously affected by Tsunami. Fifty families, which involved in fisheries industry, are directly interviewed using a structured

Proceedings of the International Forestry and Environment Symposium 2006 of the 
questionnaire. Observation method is also used to gather some of the sensitive data which can not be collected through a questionnaire. The descriptive statistical tools are used for analysis.

The study has found that sixty four percent of the people lost more than fifty percent of their properties which have been used in fisheries industry, still their core competency remains with the same industry as per their education level and the experience. Conducting short term business and psychological counseling and training programmes, facilitating through low-interest loan schemes, providing technological and marketing supports, developing a multiple village production cluster approach and conducting intensive vocational skill transferring programmes are recommended as short and medium term strategies. Establishing Godawaya village, with necessary infrastructure facilities, as an economic hub due its uniqueness in location is the main long term strategy.

\section{$\underline{093}$ \\ Designing green belts in the coastal zone of Hambantota

\author{
N I Kalasinghe ${ }^{1}$, and D M S H K Ranasinghe ${ }^{2}$ \\ National Aquatic Research Agency (NARA), Mattakkluliya, Sri Lanka. \\ ${ }^{2}$ Department of Forestry \& Environmental Science, University of Sri Jayewardenepura
}

Tsunami, which occurred in the Indian Ocean on $26^{\text {th }}$ of December, 2004 caused severe damage to Sri Lanka's coastline. Hambantota District, situated in the south of the country was among the worst affected. 19 GS Divisions in the Districts were affected. As a measure towards protection of the coastline from future such hazards, establishment of a green belt has been suggested by the Government. The location of this belt was proposed to be in the strict conservation zone of the coast which was $100 \mathrm{~m}$ in the western coast and $200 \mathrm{~m}$ in the eastern coast. The limits were then revised and the present reservation limits were in accordance with those listed in the Revised Coastal Zone Management Plan 1997.

The present study was conducted with a view to design a green belt for Hambantota District. It was hoped to recommend the most suitable species and their arrangement taking into consideration the natural landscape features of the coastline. Further, the modalities of the implementation of such a belt also was discussed with the existing organisations in the District including govt,, non govt, private and the communities.

The exact study area was limited to the coastline between Kudawella to Kubukkan Oya. Data were collected in 12 sampling locations. The methods used for data collection were, reconnaissance survey, floral sampling, focal group discussions and community survey. In the floral sampling, a transect of $10 \mathrm{~m} \times 50 \mathrm{~m}$ was established from the beach towards the inland at each sampling location and all the species were identified. The intention of this was to identify the species which are most resistant to coastal hazards. Focal group discussions were held with the key players in the green belt establishment in the District. The main aim of this was to identify their level of support and willingness to participate in the Green Belt.

According to the results, the coastline of Hambantota can be divided into natural, rural and urban areas. Among the natural areas, mangroves and sand dunes were prevalent. Recommendations are given in the use of most suitable plants for individual areas in the District ie Rekawa, Yala National Park. Mahalewaya, Rathupasgodalla and rural areas. Many govt, and non govt. organisations were involved in tree planting. However, there was no coordinated effort. The neighbouring communities expressed their willingness to participate in this exercise especially in tree planting and maintenance.

Proceedings of the International Forestry and Environment Symposium 2006 of the 